\title{
PELEBARAN JALAN UMUM DALAM KOMPLEK PERUMAHAN LIMBUNGAN PERMAI (PLP) RT.02 RW.06 KELURHAN LEMBAH SARI KECAMATAN RUMBAI PESISIR PEKANBARU RIAU
}

\author{
Husni Mubarak ${ }^{1)}$, Alfin Surya ${ }^{2)}$ \\ 1) Program Studi Teknik Sipil Universitas Abdurrab \\ 2) Program Studi Analis Kesehatan Universitas Abdurrab \\ Email: alfin.surya@univrab.ac.id
}

\begin{abstract}
ABSTRAK
Kegiatan Kukerta Universitas Abdurrab dilakukan sebagai bentuk pengabdian dan refleksi dari peran mahasiswa sebagai Agent of change. Jalan menurut KBII diartikan sebagai adalah prasarana transportasi darat yang meliputi segala bagian area darat, termasuk bangunan pelengkap dan perlengkapannya yang diperuntukkan bagi lalu lintas, yang berada pada permukaan tanah, di atas permukaan tanah, di bawah permukaan tanah dan/atau air, serta di atas permukaan air, kecuali jalan kereta api, jalan lori, dan jalan kabel. Pelebaran jalan dilakukan guna memberikan keleluasaan dan kenyamanan para penguna jalan yang berada di area Perumahan Limbungan Permai. Dalam pembagiannya jalan yang mendapat pelebaran adalah jalan Umum yang bisa dilalui oleh masyarakat umum sebagai prasarana transportasi dan mobilisasi penduduk. Pelebaran sendiri dapat di artikan sebagai penambahan lebar yang semulanya sudah ada, namun dirasa kurang dan oleh karena itu dilakukanya pelebaran jalan sebagai salah satu bentuk pengabdian masyarakat.
\end{abstract}

Kata kunci : Jalan, Prasarana, Pelebaran, Masyarakat.

ABSTRACT

Abdurrab University's Kukerta activities are carried out as a form of devotion and reflection on the role of students as Agents of change. Roads according to KBII are defined as means of land transportation infrastructure that covers all parts of the land area, including complementary buildings and equipment intended for traffic, which are on the ground, above ground, below ground and/ or water, and above water level, except railroad tracks, lorries, and cable roads. Road widening is done to provide flexibility and comfort to road users in the Permai Limbungan Housing area. In its distribution, the road that gets widening is a public road that can be passed by the general public as transportation infrastructure and population mobilization. Widening itself can be interpreted as an addition to the width that originally existed, but it was deemed insufficient and therefore the widening of the road was done as a form of community service.

Keywords: Road, Prasarana, Widening, Society. 


\section{PENDAHULUAN}

Perumahan Limbungan Permai RW 06 RT 02 Kelurahan Lembah sari Kecamatan Rumbai Pesisir Pekanbaru Riau merupakan lokasi dari Kukerta (Kuliah Kerja Nyata) Universitas Abdurrab tepatnya ditempati oleh kelompok 8. Kegiatan Kukerta dimulai pada tanggal 4 Juli 2019. Ada beberapa program kerja yang sudah disiapkan untuk Kukerta kali ini, salah satu program unggulan kukerta kelompok 8 adalah pelebaran jalan komplek PLP. Pelebaran jalan dilakukan karena melihat adanya ruas jalan yang tertutup oleh rumput liar. Ruas jalan selebar $0,5 \mathrm{~m}$ yang dipenuhi rumput liar serta sampah juga disebabkan banyaknya rumah yang kosong sehingga tidak terawat dan juga dapat menimbulkan penumpukan sampah, oleh karena itu pelebaran jalan di sisi kiri dan kanan diharapkan dapat memberikan fungsi yang optimal untuk warga masyrakat sendiri.

Jalan menurut KBBI sendiri adalah prasarana transportasi darat yang meliputi segala bagian area darat, termasuk bangunan pelengkap dan perlengkapannya yang diperuntukkan bagi lalu lintas, yang berada pada permukaan tanah, di atas permukaan tanah, di bawah permukaan tanah dan/atau air, serta di atas permukaan air, kecuali jalan kereta api, jalan lori, dan jalan kabel. Jalan raya adalah jalur - jalur tanah di atas permukaan bumi yang dibuat oleh manusia dengan bentuk, ukuran dan jenis konstruksinya sehingga dapat digunakan untuk menyalurkan lalu lintas orang, hewan dan kendaraan yang mengangkut barang dari suatu tempat ke tempat lainnya dengan mudah dan cepat. (Clarkson H. Oglesby. 1999). Pelebaran jalan yang dilakukan di mulai dari komplek J dan berakhir di ujung komplek K yang memiliki panjang $100 \mathrm{~m}$. Kegiatan pelebaran jalan ini dilakukan dengan menambah ruang pada sisi kanan dan kiri jalan. Pada awalnya jalan ini hanya memiliki lebar 5 meter saja. Pada sisi kanan jalan maupun sisi kiri jalan akan ditambah ruang yang sama besarnya, yaitu $0,25 \mathrm{~m}$. Sehingga, total pelebarannya sebesar $0,5 \mathrm{~m}$. Untuk panjang jalan yang akan dilebarkan, rencananya sepanjang 70 meter.

Pelebaran jalan ini dilakukan berdasarkan dari saran dan respon masyarakat sekitar terhadap jalan komplek terkhususnya di blok tersebut sering mengalami hambatan apabila ada sudah ada 2 kendaraan minibus yang lewat dari arah yang berlawanan, selain itu sisi kiri kanan jalan yang di dominasi tanah lunak dapat membahayakan kendraan yang lewat maupun yang akan parkir. Tekhnik pelebaran jalan ini mengunakan metode perkerasan jalan. Pekerasan jalan adalah campuran dari bahan-bahan yang digunakan untuk mengikat matrial pembuat jalan itu sendiri, konstruksi pekerasan jalan yang di gunakan adala Konstruksi perkerasan kaku (rigid pavement), yaitu perkerasan yang menggunakan semen (portland cement) sebagai bahan pengikat. Plat beton dengan atau tanpa tulangan diletakkan diatas tanah dasar dengan atau tanpa lapis pondasi bawah. Beban lalu lintas sebagian besar dipikul oleh plat beton. ( Sukirman 1992 ). Pengabdian ini bertujuan untuk melakukan pelebaran jalan yang nantinya dapat memberikan dampak positif untuk masyarakat sekitar, dampak yang dapat di rasakan nantinya adalah kelancaran jalan dan juga kemudahan masyarakat sekitar untuk beraktifitas. 


\section{TINJAUAN PUSTAKA}

Pengertian jalan raya adalah:

1. Jalur-jalur tanah di atas permukaan bumi yang sengaja dibuat oleh manusia dengan bentuk, ukuran-ukuran dan konstruksinya sehingga dapat digunakan untuk menyalurkan lalu lintas orang, hewan dan kendaraan yang mengangkut barangbarang dari tempat yang satu ke tempat yang lainnya dengana cepat dan mudah. (Silvia Sukirman, 1994).

2. Prasarana transportasi darat yang meliputi segala bagian jalan, termasuk bangunan pelengkap dan perlengkapannya yang diperuntukkan bagi lalu lintas, yang ada di atas dipermukaan tanah, di bawah permukaan tanah dan/atau air, serta di atas permukaan air, kecuali jalan kereta api, jalan lori, dan jalan kabel.(Wilkimedia. Jalan Arteri.com). Menurut Undang-undang No.38/2004 jalan pengertian jalan adalah:

a. Jalan adalah prasarana transportasi darat yang meliputi segala bagian jalan, termasuk bangunan pelengkap dan perlengkapannya yang diperuntukkan bagi lalu lintas, yang ada di atas dipermukaan tanah, di bawah permukaan tanah dan/atau air, serta di atas permukaan air, kecuali jalan kereta api, jalan lori, dan jalan kabel. 7

b. Jalan umum adalah jalan yang diperuntukkan bagi lalu lintas umum.

c. Jalan khusus adalah jalan yang di bangun oleh instansi, badan usaha, perseorangan, atau kelompok masyarakat untuk kepentingan sendiri.

d. Jalan tol adalah jalan umum yang merupakan bagian sistem jaringan jalan dan sebagai jalan nasional yang penggunannya diwajibkan membayar biaya tol.

Klasifikasi menurut fungsi jalan sesuai dengan Tata Cara Perencanaan Geometrik Jalan Antar Kota No.038/TBM/1997 terbagi atas:

1. Jalan Arteri: jalan yang melayani angkutan utama dengan ciri-ciri perjalanan jarak jauh, kecepatan rata-rata tinggi, dan jumlah jalan masuk dibatasi secara efisien.

2. Jalan Kolektor: jalan yang melayani angkutan pengumpul/pembagi dengan ciriciri perjalanan sedang, kecepatan rata-rata sedang dan jumlah jalan masuk dibatasi.

3. Jalan Lokal: jalan yang melayani angkutan setempat dengan ciri-ciri perjalanan jarak dekat, kecepatan rendah, dan jumlah jalan masuk tidak dibatasi.

\section{METODE PELAKSANAAN}

Kegiatan pelebaran jalan dilakukan di RW 06 RT 02 Perumahan Limbungan Permai kelurahan Lembah Sari kecamatan Rumbai Pesisir kota Pekanbaru. Kegiatan pelebaran jalan dilaksanakan selama 2 (dua) minggu dengan melibatkan seluruh anggota kelompok 8 Kukerta dan juga Masyarakat RW 06 RT 02 Perumahan Limbungan Permai. Kegiatan pelebaran jalan dilaksanakan dalam dua tahapan, yaitu persiapan dan pelaksanaan. Tahapan persiapan meliputi observasi permasalahan mitra, sosialisasi rencana kegiatan, penyiapan alatdan bahan, serta persiapan keseluruhan. Tahapan persiapan meliputi pengukuran jalan yang akan di lakukan pelebaran, melakukan perhitungan untuk bahan yang akan digunakan, melakukan persiapan untuk alat yang nantinya akan digunakan sewaktu pelaksanaan. Hal 
terakhir yang di lakukan pada fase persiapan adalah menghitung jumlah bahan-bahan yang akan digunakan (material) yang berkaitan dengan pelebaran jalan.

Tahap kedua adalah tahap pelaksanaan yang di mulai pada hari ke 2 sampai dengan hari terakhir. Bahan bahan yang digunakan adalah : semen bubuk 6 sak, batu-bata 1500 batang, pasir 2 mobil pickup serta air yang dipergunakan untuk melarutkan adonan semen dan pasir. Untuk metode campuran sendiri mengunakan campuran yang digunakan dalam standar adukan jalan beton yaitu 3-2-1 yang terdiri dari semen, pasir dan air. Jalan yang akan dilakukan pelebaran sepanjang $70 \mathrm{~m}$ dengan jalan semula yang memiliki lebar $5 \mathrm{~m}$ dan sisi yang akan di lebarkan adalah $25 \mathrm{~cm}$ per ruas jalan atau kiri dan kanan.

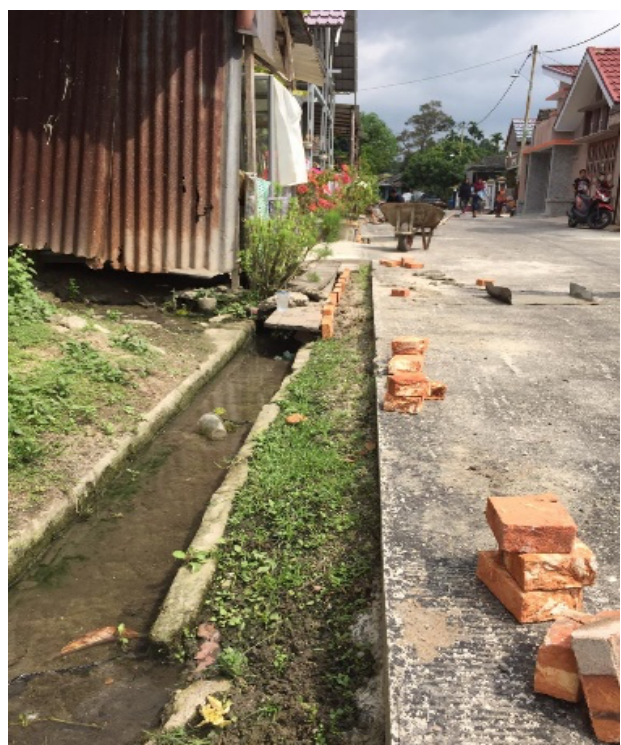

Gambar 1. Kondisi Jalan Sebelum Pelebaran

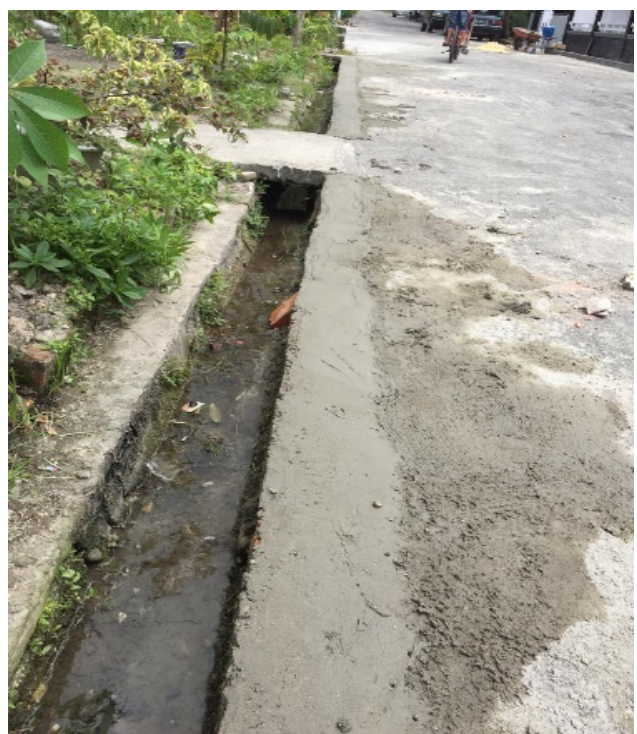

Gambar 1. Kondisi Jalan Setelah Pelebaran 


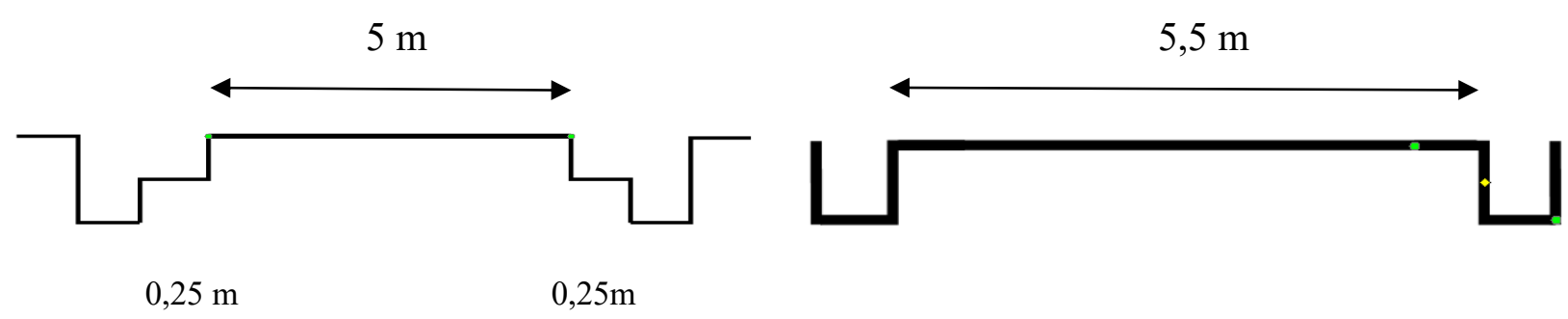

Gambar 3. Ilustrasi Jalan Sebelum dan Sesudah Pelebaran

\section{HASIL DANPEMBAHASAN}

Kegiatan pelebaran jalan ini dilakukan dengan menambah ruang pada sisi kanan dan kiri jalan. Pada awalnya jalan ini hanya memiliki lebar 5 meter saja. Pada sisi kanan jalan maupun sisi kiri jalan akan ditambah ruang yang sama besarnya, yaitu 0,25 m sehingga total pelebarannya sebesar $0,5 \mathrm{~m}$. Untuk panjang jalan yang akan dilebarkan, rencananya akan sepanjang 70 meter. Dalam pelaksanaannya sendiri, jalan yang sudah dilebarkan sepanjang 50 meter. Pelebaran jalan ini juga dilakukan atas bentuk pengabdian masyarakat yang dilakukan oleh kelompok 8 Kukerta Univrab 2019.

Komposisi bahan yang digunakan untuk kegiatan pelebaran jalan ini membutuhkan semen, pasir dan kerikil. Untuk takaran bahan, perbandingannya semen:pasir:kerikil yaitu 1:2:3. Misalnya saja, jika semen yang digunakan beratnya $2 \mathrm{~kg}$, maka akan membutuhkan 4 $\mathrm{kg}$ pasir dan $6 \mathrm{~kg}$ kerikil. Sebelum dilakukanya pelaksanaan hal pertama yang dilakukan kelompok Kukerta 2019 adalah melakukan pembersihan ruas jalan yang akan dilakukan pelebran, dibersihkan dari rumbut dan batu batu serta benda yang menganggu lainya.

\section{KESIMPULAN}

Pelebaran jalan yang dilakukan oleh mahasiswa Kukerta Univrab 2019 tepatnya kelompok 8 merupakan salah satu bentuk dari pengabdian masyrakat yang menjadi satu dari sekian banyak indikator peningkatan sumber daya manusia dan fungsi dari mahasiswa sendiri serta Universitas. Pelebaran jalan yang dilakukan berangkat dari hasil observasi yang dilakukan oleh kelompok 8 bersama dengan Dosen Pembimbing Lapangan (DPL), setelah melakukan observasi yang mendapatkan beberapa hasil dan melahirkan beberapa program kerja yang dilaksanakan di RW 02 kelurahan Lembah Sari kecamatan Rumbai Pesisir Riau. Program kerja pelebaran jalan yang dikerjakan selama 3 minggu ini meliputi 3 tahap proses antara lain : persiapan dan kajian bahan, pelaksanaan serta finishing yang merupakan tahap akhir dari program kerja pelebaran jalan ini. Banyaknya rumah yang kosong di areal sekitar pelebaran jalan di Perumahan Limbungan Permai menyebabkan banyaknya rumput liar yang mengisi ruas jalan yang belum mendapat semenisasi yakni selebar 0,25 $\mathrm{m}$ di setiap sisinya, jalan sepanjang tersebut juga sering terjadi penyumbatan arus jalan apabila ada 2 kendaraan minibus yang berjalan dengan arah yang berlawanan. Jalan yang sudah lebarkan tersebut diharapkan dapat bermanfaat bagi masyarakat sekitar dan membantu sedikit permasalahan yang terjadi di Perumahan Limbungan Permai. 


\section{DAFTARPUSTAKA}

[1]. Fitri Wulandari. 2018. Analysis of Performance and Effects of Road Widening and [2]. Gadjah Mada University Press. 2017 .Panduan Kukerta Univrab 2019.

[3]. Median Road Making (Case Study of Jalan Temanggung Tilung, Palangkaraya City).https://doi.org/10.33084/mits.v7i1.685

[4]. Melkiamus Dedimus Randu. Vol 2. No 1.2017.Pengaruh Pelebaran Ruas Jalan terhadap Perubahan Kapasitas Jalan dan Lingkungan. Nirwani Puspasari 2000. 